\title{
The Analysis of Some Jokes by Using the Concept of the Context of Situation
}

\author{
Eda Maaliah ${ }^{1}$, Alief Sutantohadi ${ }^{2}$,Yulius Harry Widodo ${ }^{3}$, Ita Permatasari ${ }^{4}$, Moh. Farid Maftuh ${ }^{5}$ \\ Madiun State Polytechnic ${ }^{1}$, Campus I, Serayu Street No. 84, \\ Taman Madiun City, East Java, Indonesia ${ }^{1,2,3,4,5}$ \\ \{eda@pnm.ac.id $\}$
}

\begin{abstract}
This research is an attempt to apply linguistic analysis on joke itself. The joke is chosen to examine how the analysis of the context of situation of a text can give the aim in achieving a precise understanding of particular text. The aim of this research is to figure out the advantages be gained from the analysis of the jokes by using the concept of the context situation. The method that is used is qualitative descriptive. The data are Gus Dur's jokes taken from Guntur Wiguna Book "Koleksi Humor Gus Dur". It uses descriptive analysis. The results of the research are the first, what the messages of the jokes are. The second, what the messages that are conveyed by the author and the speaker. Then, the kind of some jokes, that is the social protest jokes. To analyze the social context of a text, it involves three headings: the field, the tenor, and the mode. The conclusion is on the analysis of the jokes, the writer found there are some meanings are delivered by the speaker. The rationale of the analysis of a discourse through the knowledge of context can be found.
\end{abstract}

Keywords: Context of Situation, Humor Gus Dur, Discourse Analysis.

\section{Introduction}

Talking about KH. Abdurahman Wahid called Gus Dur, there are many interesting things to discuss, especially in terms of jokes. Gus Dur is the funny priest from Jombang East Java. $\mathrm{He}$ is the funniest president in the wolrd. It can be founded from Guntur Wiguna's Koleksi Humor Gus Dur. There, Gus Dur transferred his ideas, feelings, messages, and also thoughts into jokes. He always tried to express everything he saw and heard because he is educated to be critical and also skeptical to react to all problems and events that appeared around him, or even around the world. In this research, the joke is chosen to examine how the analysis of the context of situation of a text give contribution in achieving a precise undersatnding of a particular text. Halliday said that test is whatever we write that looks as thought it is made of words and sentences [1]. But it is not something that can be defined as being just another of words and sentences, it is essentially a semantic unit. Thus, in this case, the text is the joke. This research is an attempt to apply linguistic on joke itself.

Linguistics, according to Oxford Learner's Dictionary is the science of language, e.g. of its structure, acquisition, and relationship to other communication forms [2]. The analysis of language is is done systematically by making objective observations of actual language data 
within the framework of some general theory of language structure[3]. Moreover, according to Guy Cook, there are two kinds of languages as potential objects to study [4]. The first one, it is abstracted to teach language or literacy and is functionated to learn how the rules of language work. Next, it is used to express something and is felt to be coherent, and it involves language in use, in this case, for communication, and called Discourse. Brown and Yule stated discourse analysis discusses : 1 . how language to communicate is used by human, and 2 . in particular, how linguistics messages are constructed by addressers in order to interpret them, and how forms of language are used in communication [5]. From the explanations above, it is clear that as a means of communication, language commonly uses two different ways in transferring ideas, messages, feelings, thought, etc. Those ways are spoken and written media. Joke is as one of the application forms in transferring them, is something interesting to observe and research.

\section{Literature Review}

There are some previous studies related to the topic. The implicatures of the utterances are used in these studies.. Those studies focus on the conventional implicature and the maxims vilating. While in the study, the writer focusses on analyzing jokes using the concept of the ontext of situation. The writer focusses on one book about Gus Dur's jokes collected by Guntur Wiguna, who is very respect to Gus Dur's figure.[6] There are some transcripts with the three headings : field, tenor, and mode for analyzing of each transcript. After giving these three heading, the writer explains the transcript using situasional descriptions..

\subsection{Discourse Analysis}

Discourse is said by Nunan as a continuous strecth of (especially spoken) language larger than a sentence, it often makes up a unit of coherent, as well as a sermon, joke, or narrative [7]. There are many meanings and definitions of the term "discourse". Discourse was explained in the first as dialogue or interaction a speaker and a listener. Therefore, discourse reffered to authentic daily communicaties, mainly oral, and the wide communicative context included. The term discourse was then also used to refer to the totality of condified language used in a particular field intellectual inquiry and of social practice. Michael Foucalt states it is as "system of thought composed of ideas attitude, course of action, belief, and practice that systematically constructs the subjects and the words of which they speak [8]. In linguistics, in general, it is considered to be the use of written or spoken language in social context.

The term Discourse Analysis for the first time was invented in 1952 by Zellig Harris [9]. He started a search for language rules that would explain how sentences were connected within a text by a kind of extended grammar. An advertisement for hair tonic was analyzed by him, then looked for explaining one sentence after another through grammatical rules. The analysis details are not so important to us, but he made an interesting conclusion. He stated that there are two possible directions in analyzing discourse. At a time "continuing descriptive linguistics" beyond the limits of a single sentence is the first. The second is "correlating culture and language". It involves no-linguistics and linguistic behavior.

\subsection{Text and Context Situation}


Text and context are the terms which cannot be separated straightly. They both are aspect of the same process. In real life, contexts come before texts, and situation is prior to the discourse that relates to it [10]. Context is a text that accompanies other text. It is something that can be said and written. It also includes other non verbal goings on the text in the total environment. Thus, because of the text's nature as semantic unit, text has to be considered as a product or as a process. As a product, text is something that can be recorded and studied, because it can be represented in systematic structures. Whereas, as a process, text is a movement and is a product of its environment. There is a continuous process of semantic choice which produces an object of social meaning of situations in a particular context.

The term of context situation was introduced for the first time by antropologist, Bronislaw Malinowski in 1923 and 1935. Malinowski tended to take cultural background as the basis in every research, as the result of his research on Kriwinia language, at one of the Pacific's islands which arouse the study of functional language linguistically. The culture that he was studying was, naturally, as different as it was possible to be from the culture that is familiar to Westerners. He tried to translate the texts of Kriwinai language into English, but it was unintelligeble to the English readers. His principal technique, however, was to provide a rather extended commentary. It can be connected to the concept of context, that is to say, the words and the sentences before and after the particular sentence that one was looking at. Then, Malinowski made the concept of context situation, that is the situation in which that text is uttered [11].

Malinowski tried to give more than the environment of the text, such as the total cultural background, not only about what was happening at the time but also what whole cultural history behind the participants, and behind the kind of practices that they were engaging in, whether practical or ritual. Then Malinowski introduced the two notions as the results of his research. The first is what he named context situation and the other is context culture. He considered that both of them are needed to get the clear text understanding. Context culture was presented because in any kind of society's daily conversation the total cultural background behind the society always appeared [11]. Whereas, the concept of situation is the context in which the conversations as text unfolds. It was Firth who formulated the description of the context situation for the first time. The headings are :

a) The Participants in the situation : is referred to the the participants' statues and roles.

b) The Participants' Action : is referred to what the participants do, include verbal / non verbal action

c) Other features which are relevant of the situation : is referred to the objects and events in the surrounding.

d) The effect of the verbal actions : what changes happened in the situation [11].

\subsection{Humor in Human Life}

Laugh makes us life cheerful. It is good for us not only physically but also mentally. The advantages of healthy laugh can be enjoyed by young or old people, without differing their age, social background, and experience. Although laugh cannot make our problems disappear directly, a humor approach toward life can help us to look all problems from another point of view. It gives a resistance to start again and to face disappointment. In addition, humor can also decrease tension and mental stress as the result of many problems that make us restless and lose patient. But ofcourse, the humor is useful or not also depends on the situation and the condition at that time.[12] 
Moreover, Ancok says that if we continually convey humor not at the exact place and situation, it will cause a negative effect to us. For instance, someone who always laugh as the consequence of humor, at last he does not work instead. He becomes unproductive, while in this case, humor can stimulate someone's productivity. Hearing, reading, or seeing humor, can make all of someone's burdens, frustatitions, and sign less. Humor is a kind of recreation, because by enjoying the cheerful atmosphere, our psyche will become more comfortable physiologically, and finally we can get more recreations [13]. Hence, with the varieties of their multicomplex potential, humor forms whatever they called [14], are ready to be used efficiently as :
a) Introspection
b) Immune system toward spiritual disease
c) Social control mechanism
d) Productivity increase
e) Lubricant in communication between people who are always threatened by distorsion
f) Expansion of our insight in solving problems
g) Effort in seeding love and affection, and exterminating hate
h) Element of opinion and social solidarity
i) Faith

\subsection{Joke as One of the Forms of Humor}

According to psycholanalysis, sublime process is one of someone's mechanism of psyche protection forms. By using joke as protection, someone can convey his agrressiveness safely, without worrying that society will take a measure to it. It will be different if the agrressiveness is still in a rumor form. He will be considered he is having done a subversive activity by someone or people who feel that they have been done a subversive activity by someone or people who feel that they have been the target of the aggressivion [15].

\section{Research Methodology}

This research uses the qualitative design. According to Cresswell, it is ascribed to a social or human problem in exploring and understanding the meaning individuals or groups.[16] It involves procedures of data collection, which are mainly in non-numerical data.[17] Therefore, this research tries on describing the context of situation of some of jokes in Guntur's Koleksi Humor Gus Dur. The data of the research in this study are some of Gur Dur jokes taken from Guntur Wiguna's Koleksi Humor Gus Dur. There are many jokes, anecdotes, and also puzzles which are divided into some kinds of humor. The humor forms are written by some sources collected by Guntur Wiguna they are the humor forms that spread in the surroundings.[6] But this research takes only some of the jokes in the book. The researcher tries to look for read and study some books from the library and other sources related to the topic as the references and collected the important things from the books concerning with the context of situation.

This research uses descriptive analysis. It does not only collect and arrange the data but also analyze and interpret the data.[18] The decriptive analisis is used to analyze the data by the context situation study and interpretations of the condition that exists. This research uses qualitative data type. The data is in the form of words. As stated by Lawrence Neuman that qualitative data tend to be in the form of words, sentences, and paragraph are more than 
numbers.[19] In this case, the data is Gus Dur's jokes. Thus, to make clearer, the researcher presents the process of analysis and making some explanations as seen from the diagram below :

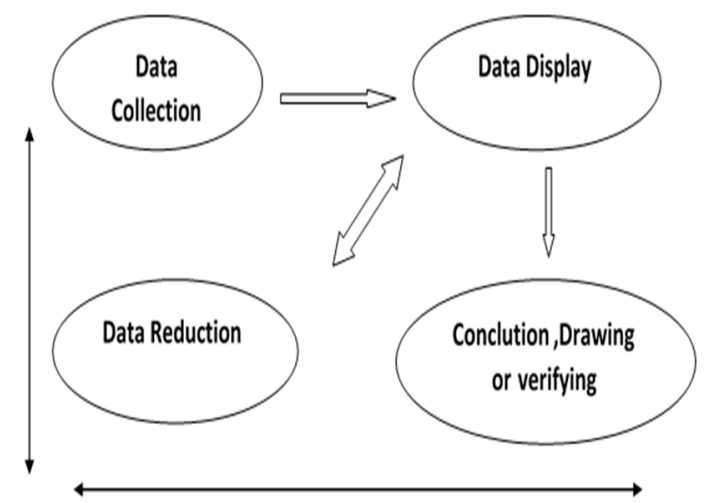

Fig. 1. Data analysis process

\section{Research Result and Discusion}

In analyzing a discourse or a text, according to Lubis, we firstly must understand the context factors, such as the situation, speaker, condition, hearer, the topic of the text, etc. Exactly to know, the meaning in real of a text, we must know its context and also situation. Because they both determine meaning. Furthermore, Halliday gives us a concept of situation involving three headings. The Field, the Tenor, and the Mode are three headings / features which are used to analyze the social context of a text. Those headings enable us to give characterization of the nature of many kinds of text for similar texts in any language [11].

\begin{tabular}{|ll|}
\hline $\begin{array}{l}\text { Feature of context } \\
\text { field: what the }\end{array}$ & Function of language \\
text is about & ideational metofunction \\
tenor: the relationship & \\
between speaker/writer & \\
and listener/reader & interpersonol metofunction \\
mode: how the text & \\
is constructed & textual metofunction \\
\hline
\end{tabular}

Fig. 2. three feautures in any context situation

From the figure above, it is clear that field is what the text about, tenor is the relatioship between speaker/writer and listener/reader, and then mode refers to how the text is constructed 
[11]. According to Wiguna (2017) it can be founded, there was a relationship between the society and the language he used. Gus Dur is a strange priest [6]. He likes to sleep anywhere, during Friday prayer, at the meetings, even when he is as a speaker. Despite his phenomenal and controversial figure, Gus Dur has taught us to enjoy the beauty of diversity, to give those who deserve it the right to see things from a brader perspective. He responded to everything lightly, with his witty jokes, ans was vey straight forward. Moreover, before we discuss Gus Dur's jokes by using the concept of the context of situation, it would be better to classify the jokes into categories with some examples. The categories of jokes in Guntur Wiguna's Koleksi Humor Gus Dur are :

a) The jokes are telling about Ethnics or nations in the world. Eg: "Horas Gaya Jawa"

b) The jokes are telling about foolish people, not only Indonesian but also another nation.

Eg : "Jin and Tiga Manusia"

c) The jokes are telling about smart Indonesian people . Eg: "Perokok Berat"

d) The jokes are telling about Figure. Eg : "Senjata Makan Tuan, Ajaran Makan Guru"

Transcript 1 is joke about ethnics or nations HORAS GAYA JAWA telling about they way of greetings to the Indonesian people in each of the territory, with difeerent ethnics, from the different places.

\section{Transcript 1:}

Dalam menyampaikan pengantar pidato kenegaraan meyambut HUT ke-55 RI itu Gus Dur juga menyinggung soal keragaman etnis di Indonesia. Maka, kata Gus Dur, jangan heran kalau ada anggota DPR yang berasal dari Sumatra Utara menyapa dengan horas sebagai salam hangat perkawanan.

Sebagai orang yang berasal dari suku Batak, Ketua DPR, Akbar Tandjung tak mau kalah dengan Gus Dur yang berasal dari Jawa itu. Maka selesai Gus Dur memberikan pidato, Akbar pun langsung menimpali. "Saya juga orang Batak," kata Akbar, yang beristri orang Solo. "Tapi kalau orang Batak seperti saya, yang sudah lama di Jawa, akan beda mengucapkannya."

"Lho, di mana pula letak perbedaannya, Bah"

“Ya, orang Batak yang lama di Jawa seperti saya ini akan mengatakan horaaa....s, " ujar Akbar dengan nada lembut.

\section{Situational description}

a) Field : the pedigree of the Indonesian people's language; an unreasonable action

b) Tenor : Indonesian People ; the joke is for society and for readers.

c) Mode : It is an informal written, and to be collected or entered into a book finally.

The field is giving the Indonesia people's language from the different places of the ethnic language that is done by turn. It is an unreasonable action : take a piece of language in greeting from the different places and speak it up with different ethnic, they (Indonesia people) who are from a certain place then live in another different place will adapt the language where they live. The tenor is the Indonesian People in the whole of the Indonesia's territories, Java, Batak, and the other ethnics. The relationship between the society from one ethnic and another ethnic of Indonesia is that, the people who always speak using their own languange as their need of lives. The joke is for the society and the readers.

The mode is an informal written, and to be collected or entered into a book finally; the joke is just a media to dcrease mental stress and surfeit; it is used in a relaxed conversation; the 
text/joke is a short story and semi dialogue, in which in the story in the joke itself sometimes happens around the environment of society.

\section{Interpretation}

This joke is a satire and also insulting toward the regions in some different places in Indonesia with many territories about their development level in the national development that is lower if they are compared with the regions in the territory of another place. In fact, it is indeed so. The mens of public in a various sectors, such as education, intonation, volume of voice etc in Batak territory are most high intonation if they are compared with the people from central java. For instance, the people who are from Batak then marry with the people from Solo, then live for several years di Solo, automatically he has lower intonation in speaking, using different language. An established fact that, in whatever sectors are, the development always needs the resources, such as human being (the quantity and quality/skills), capital, another media (information, transportation, etc), etc [20]. Transcript 2 is a joke about foolish people entitled JIN DAN TIGA MANUSIA telling about a boat which brings many passengers. There are 3 passengers who are safe, they are from French, America, and Indonesia. They want a comfortable life with a genie's help.

\section{Transcript 2:}

Menurut Gus Dur, pernah ada sebuah kapal berisi penumpang berbagai bangsa karam. Ada tiga orang yang selamat, masing-masing dari Perancis, Amerika, dan Indonesia. Mereka terapung-apung di tengah llautdengan hanya mengandalkan sekeping papan.

Tiba-tiba muncul jin yang baik hati. Dia bersimpati pada nasib bangsa manusia itu, dan menawarkan jasa. "Kalian boleh minta apa saja, akan kupenuhi,"kata sang jin. Yang pertama ditanya dalah si orang Perancis.

"Saya ini petugas lembaga sosial di Paris, " katanya.

"Banyak orang yang memerlukan tenaga saya. Jadi tolonglah saya dikembalikan ke negeri saya. "Dalam sekejab, orang itu lenyap, kembali ke negerinya.

“Kamu, orang Amerika, apa permintaanmu?” Kata sang jin.

"Saya ini pejabat pemerinta. Banyak tugas saya yang terlantar karena kecelakaan ini. Tolonglah saya dikembalikan ke Washington, "kata orang Amerika itu.

"Oke," kata jin, sambil menjentikkan jarinya. Dan orang Amerika lenyap seketika, kembali ke negerinya. "Nah, sekarang tinggal kamu orang Indonesia, sebut saja apa maumu, "Sang jin menawarkan permintaan.

"Duh, Pak Jin, sepi banget di sini,"keluh si orang Indonesia. "Tolonglah kedua teman saya tadi dikembalikan ke sini."

"Zuuuuuuttt!!, orang Perancis dan Pria Amerika itu muncul lagi dengan wajah bingung.

\section{Situational description}

a) Field : a wish for comfortable life with a geni's help; an amoral and unreasonable action

b) Tenor: three safe passengers and a genie who has magic power; the joke is for society and readers

c) Mode : the mode is the same as transcript 1

The field is a wish of each safe passenger for comfortable life with a genie's help that is done one by one. It is an amoran and unreasonable action; three passengers lost in the sea, the they see a genie and ask him whatever they want to. The tenor is three safe passengers and a 
genie who has magic power. The relationship between three safe passengers and the genie is that they are both the creature of God but in the different nature. Sometimes the two different creatures can meet in the same nature (supernatural). The joke is for the society, and readers. The Mode is the same as transcript 1 . And it is an amusing story, and only based on fantasy with irrational event.

\section{Interpretation}

The joke indicates the situation of the majority of people in the world who are still poor. In the middle of uproarious national development, millions of poor people, not only in villages but also in cities, only become the sad spectators of the other people's progress around them. As the result, there is a term 'social gap' the prosperity imbalances between the rich and the poor people that is seen so striking in front of our eyes. The rich people enrich themselves without a care of the misery of the people around them. In the middle of the modern life the needs of life are so high and expensive, and opportunities for employment are so difficult to get, that many people do not have work. At last, people are inclined to take the short cut in fulfilling their needs of life, because they feel that they do not have a foothold in getting a job, such as material, education, or even skills. As a result, many people are inclined to choose to be beggars, picpockets, robbers, or even they will be killers in order to fulfil their needs.

But, this is still not so bad, because all works that are done by people above still have a real effort, although it breaks the law, social, and religious norms. There are many people who just do nothing, they only wish some luck will fall down from the sky. Or, on the other side, there are also many people who wish some luck with shaman, cemetery, or even genie's helps in order to reach their needs of life, without miseries as many rich people around them, as it is implied in the story of this joke. It is indeed true that the poverty can cause the heathenism (Al-Hadist).

This joke also indicates that it is so ironic that in the middle of development, in fact, there are millions of Indonesian people who live in poverty. What has really been done in the development, and what or who is the development for. Why, if the development is for all of the people's prosperity, it is harming the poor people? It can be proved by many cases of removal of people from their lands with the reasong they are for development, whereas in fact they are harming the poor people. If we pay close attention to the fact at this moment, it is as if the development is just for certain elite people. It makes the agents of the development become rich, and on the other side, millions of people are just as sad spectators. Transcript 3 is a joke about ethnics or nations entitled PEROKOK BERAT telling about an Indonesian who has many reasons not to stop smoking.

\section{Transcript 3}

Alkisah, semasa belajar di Mesir, Gus Dur punya teman asal Aceh, namanya Yas. Kamar mereka bersebelahan.

Yas ini betul-betul perokok berat. Ke manapun dia pergi, pasti di kantongnya selalu terselip dua bungkus rokok. Satu sudah dibuka, satu lagi buat cadangan. "Bagi dia merokok itu jangan sampai ketelatan. Makanya si Yas selalu bawa dua bungkus, ”kata Gus Dur di buku Ger-Geran bersama Gus Dur : Edisi Spesial Mengenang Gus Dur. Saking sayangnya pada temannya, Gus Dur menasihatinya,

"Yas, apa kamu enggak pernah baca tulisan di majalah bahwa tiap satu batang rokok itu bisa memendekkan umur 30 detik?"

Enteng saja Yas menggeleng, "Belum tuh.." 
"Lho, kamu itu gimana. Sekarang coba kamu itung sudah berapa tahun umurmu diperpendek oleh rokok itu. "kata Gus Dur sengit.

Sambil menyulut sebatang lagi, Bung Yas menimpali, "Ya, tapi kalau saya enggak merokok, besok saya bisa mati."

Susah memang menasihati perokok berat....

\section{Situational description}

a) Field: have many reasons not stop smoking, have short course in Mesir.

b) Tenor: two Indonesian people(students), the first is the hard smoker and the other one is his friend who advise

c) him to stop smoking; the joke is for society and readers

d) Mode: the mode is the same as text 1 , and 2

The field is having duty to study and course in Mesir. The one who has many reasons not to stop smoking, but he is very friendly with his friend. The tenor is two Indonesian people who have course in Mesir. His friend advise him to stop smoking. The relation ship between these two Indonesian people is just relationship between friends, and also a relationship between two different etnic. The one is from Java, and the other one is from Aceh. The joke is for the society and for the readers. The mode is the same as transcript 1, except that transcript 3 the story is based on fact.

\section{Interpretation}

The sentence in the joke "Ya, tapi kalau saya enggak merokok, besok saya bisa mati", indicates about the situation of hard smoker. It is right that there are many reasons from the hard smoker in order not to stop smoking. The statement is unreal / illogical if he does not smoke anymore he will die. Related to the development, we still ofter hear with so many reasons, we often hear appeals about encouragement of the national development everywhere. But in fact, the development does not increase the prosperity of all of society, but people are harmed instead. The development result can only be enjoyed by a certain group of people. And the horrifying thing is the sad spectators in the middle of the development itself (Ecpose, 1996). Transcript 4 is a joke about smart people entitled SENJATA MAKAN TUAN, AJARAN MAKAN GURU telling about a child and his father, as father who is as model/figure for his child to be wise in everything.

\section{Transcript 4}

Pada suatu hari di musim hujan, keduanya sedang duduk-duduk santai di dekat api unggun di rumahnya. Tiba-tiba sepercik api mengenai jubah tenunan dari sutera yang dikenakan sang ayah. Peristiwa itu dilihat puranya, namun ia diam saja. Setelah berfikir beberapa saat barulah ia membuka mulut.

"Ayah, aku ingin mengatakan sesuatu, bolehkah?” tanyanya

Kalau menyangkut kebenaran katakan saja, "jawab sang ayah.

"Ini memang menyangkut kebenaran, ”jawabnya.

"Silakan, ”kata sang ayah. Ia berkata, "Aku melihat benda panas berwarna merah."

"Benda apa itu?, ”tanya sang ayah.

"Sepercik api mengenai jubah ayah, ”jawabnya. Seketika itu sang ayah melihat jubah yang sebagian sudah hangus terbakar.

“Kenapa tidak segera kamu beritahukan kepadaku?, ”kata sang ayah. 
"Aku harus berfikir dahulu sebelum mengatakannya, seperti apa yang Anda nasihatkan kepadaku tempo hari, "jawab putranya dengan lugu. Sejak itu ia berjanji akan lebih berhatihati dalam memberikan nasihat pada putranya. Ia tidak ingin peristiwa pahit seperti itu terulang lagi.

\section{Situational description}

a) Field : a case of fire cloak; an unreasonable action

b) Tenor: a child and a father; the joke is for society and for readers

c) Mode: the mode is the same as transcript 1,2, and 3 .

The field is a case of fire cloak. It is an unreasonable action : smelling fire from his father's cloak make the child has a big effort to tell about the truth/fact to his father, but he must remember about his father's message to think first before saying something. Then he explains it to his father. At last they both get an agreement. Finally, his father realizes, and he promises he will be carefull in giving the advice to his child. He did not want a bitter incident like that to happen again. The tenor is a child and a father. The relationship between them is relationship between father and his child. The joke is for the society and readers. The mode is the same as transcript 1 .

\section{Interpretation}

The social gap, especially dominant sector between the major and minor people and they who get more comfort (the major people) will always exist wherever and whenever the social gap is, because, while the ideal condition has not yet become reality, the imbalance will keep, only its position is changeable (but, is there something perfect and ideal in the world?). In the imbalanced condition, the poor people must be burried, or precisely the poor (the child) must be compelled to dream. It is clear that on one side they who have overly abundant wealth, have very good life. Whereas on the other side, only for a mouthful of rice the poor people have to fight in various ways. So, dreaming is the pompous alternative for people who do not have strenght, such as children. The contradictory view seems to be more complete because for those who have overly abundant position, they do not have consciousness to understand that actually among their sufficiencies, there is still the other people's right to feel so.

For the umpteenth time the poor people are also the lossing side, for instance in the sector of law they have to submit to the situation that does not enable them to be under protection, because they can not make collusion with the court side. But, if we want to try to pay close attention to the problem, actually what is experienced by the losing side (the poor people/child) and also the rich side (father), is only a pseudo thing, because all of those are only about the worldly problems.

\section{Conclusion}

After conducting the research, the writers can conclude that some of Gus Dur's jokes, in fact, the examples of the jokes show a relation between the jokes with the environment where he lives. It can be proved that the jokes are social protest, as the reflection of his surfeit, annoyance, dissapointment, and also anger toward all parties who have link with all of the disavowals. Furthermore, by using of Concept of Situation as the analysis device, the advantages that can be reached are numerous. Firstly, we can know more about the meaning of 
the jokes are. Secondly, at least we can know what messages that are conveyed by the author and the speaker. Then, we can also know the kind of some of the jokes, that is the social protest jokes. And finally, it creates the humor effect, hints someone, ridicules someone, and to remind the readers.

\section{Acknowledgements}

We would like to thank State Polytechnic of Madiun and the commmitee of ICONEBS. We sincerelly wish to thank all participants in this research.

\section{References}

[1] M. A. K. [Halliday, An Introduction to Functional Grammar. New York: Oxford University Press, 1994.

[2] Oxford, Oxford Learner's Dictionary. Oxford University Press, 1980.

[3] L. K. Boey, An Introduction to Linguistics for Language Teacher. Singapore: University Press, 1975.

[4] G. Cook, Discourse and Literature. Shanghai: Shanghai Foreign Language Education Press, 1999.

[5] G. D. A. C. U. P. Brown, Gillian and Yule, Discourse Analysis. Cambridge: Cambridge University Press, 1984.

[6] G. Wiguna, Koleksi Humor Gus Dur. Gejayan, Yogyakarta: Penerbit Narasi (Anggota IKAPI), 2017.

[7] D. Nunan, Introducing Discourse Analysis. London: London Penguin English, 1993.

[8] M. Foucault, Discourse and Truth and Paressia. Chicago: University of Chicago Press, 2019.

[9] G. Cook, Discourse. London: Oxford University Press, 1989.

[10] R. Halliday, M.A.K. and Hasan, Language, Context, and Text: Aspect of Language in a Social-Semiotic Perspective. Victoria: Deakin University Press, 1985.

[11] R. Halliday, M.A.K. \& Hasan, Language, Context and Text: Aspects of Language in a Social- Semiotic Perspective. London: Oxford University Press, 1989.

[12] L. Blumenfeld, and Alphern, The Smile Connection. New Jersey: Prentice Hall Incorporated, 1990.

[13] D. Ancok, "Humor juga Alat Kontrol Sosial," Prisma Magazine, pp. 78-80, 1996.

[14] J. Suprana, "Humor di Tengah Masyarakat," Prisma Magazine, pp. 94-96, 1996.

[15] J. Danandjaja, Humor Mahasiswa. Jakarta: Pustaka Sinar Harapan, 1994.

[16] Creswell. J.W., Research Design: Qualitative, Quantitative, and Mixed Methods Approaches. Newburry Park: Sage Publications, 2009.

[17] Z. Dornyei, Research Methods in Applied Linguistics. New York: Oxford Universty Press, 2007.

[18] W. Surakhmad, Metode Research. Bandung: Penerbit CV Tarsito, 1990.

[19] W. L. Neuman, Social Research Methods. Massachutts. Massachutts: Allyn and Bacon Incorporated, 1991.

[20] N. Madjid, Khazanah Intelektual Muslim. Jakarta: Bulan Bintang, 1994. 